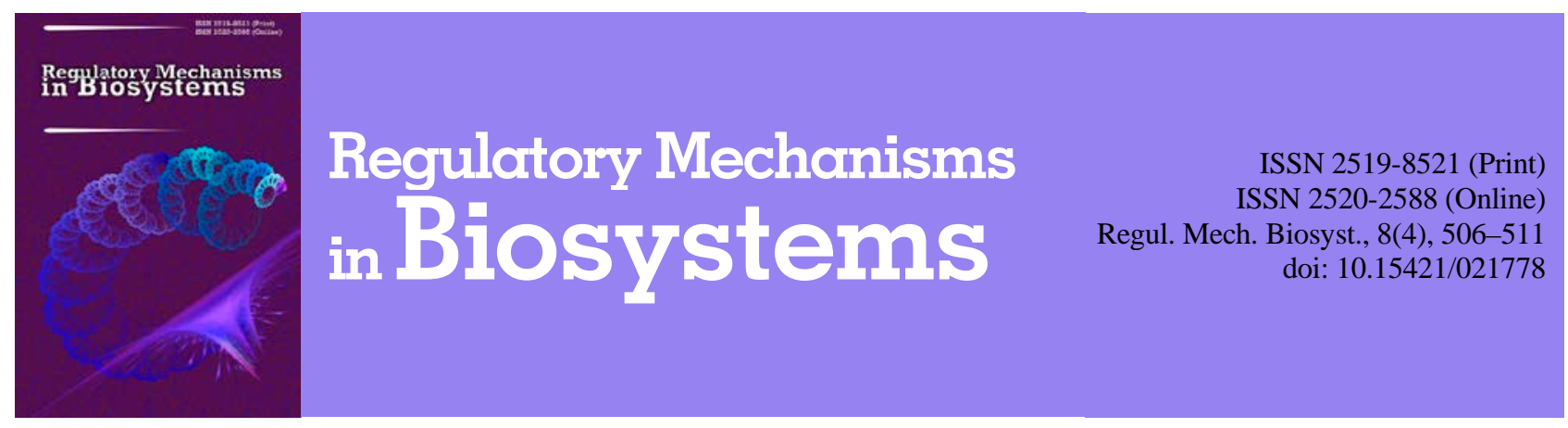

\title{
Species-specific response to acute hyperthermal stress of Haworthia (Asphodelaceae) plants
}

\author{
N. V. Nuzhyna, M. M. Gaidarzhy, Y. V. Aviekin \\ Taras Shevchenko National University of Kyiv, Kyiv, Ukraine
}

Article info

Received 04.10.2017

Received in revised form 09.11.2017

Accepted 13.11.2017

Taras Shevchenko National University of Kyiv, Symona Petlyury st., 1, Kyiv, 01032, Ukraine.

Tel. +38-067-339-97-73

E-mail: nuzhynan@gmail.com

\begin{abstract}
Nuzhyna, N. V., Gaidarzhy, M. M., \& Aviekin, Y. V. (2017). Species-specific response to acute hyperthermal stress of Haworthia (Asphodelaceae) plants. Regulatory Mechanisms in Biosystems, 8(4), 506-511. doi:10.15421/021778
\end{abstract}

An increase in environmental temperature is one of the most common stress factors for plant organisms. The study of the plants' adaptation to stress factors remains extremely important and relevant. This article presents the results of a acute short-term influence of hyperthermia on species of two subgenera of the genus Haworthia Duval. We investigated the different levels of antioxidant protection and damage degree of the members of two subgenera of the genus Haworthia at the biochemical level, measuring the lipid peroxidation, superoxide dismutase and peroxidase activities, total flavonoid content and content of photosynthetic pigments with a spectrophotometer. To determine the drought tolerance of plants, the water supply of tissues, water shortage and loss of water after an hour of wilting were measured. The values for different groups were compared by ANOVA followed by the Tukey multiple comparison test. The studied plants were warmed in a thermostat at temperatures of $40^{\circ} \mathrm{C}$ and $50^{\circ} \mathrm{C}$ for three hours under the conditions of natural light. The control group of plants was kept at $25^{\circ} \mathrm{C}$. The research has shown that $\mathrm{H}$. attenuata, $\mathrm{H}$. limifolia and $\mathrm{H}$. cymbiformis are characterized with the increase of concentration of malonic dialdehyde at $40^{\circ} \mathrm{C}$ and $50^{\circ} \mathrm{C}$, but a significant difference of values wasn’t received,which indicates the relative resistance of these plants to the influence of high temperatures. The sharp increase of temperature causes the highest level of lipid peroxidation in $H$. parksiana plants, along with which, warming to $50^{\circ} \mathrm{C}$ launches a mechanism of activation and synthesis of superoxide dismutase and flavonoids for the plants. The studied species of the subgenus Haworthia have a photosynthetic system relatively resistant to thermal stress in comparison to the subgenus Hexangulares. H. limifolia plants have a slight inhibition of photosynthesis. The adaptation of $H$. cymbiformis to thermal stress is due to the strategy of accumulation of a pool of active enzymes, superoxide dismutase, peroxidase, flavonoids under normal conditions and the activation of new peroxidase enzymes as a result of stress. $H$. attenuata is characterized by activation of new enzymes of superoxide dismutase and peroxidase under stress. It was found that $H$. cymbiformis and $H$. attenuata are more heat resistant in comparison with the other two species. Acute short-term hyperthermia has a different influence on the antioxidant system of different species of Haworthia. H. limifolia has the highest drought tolerance, H. cymbiformis has the lowest, the other two species from different subgenera have similar drought tolerance indicators. We did not find any dependence of the mechanisms of action of the antioxidant system under hyperthermia on the type of adaptation to arid conditions at the anatomical level in plants of different subgenera of the genus Haworthia.

Keywords: antioxidant system; superoxide dismutase; peroxidase; malone dialdehyde; pigments; drought resistance

\section{Видоспецифічна відповідь на різкий високотемпературний стрес у рослин роду Haworthia (Asphodelaceae)}

\author{
Н. В. Нужина, М. М. Гайдаржи, Я. В. Авєкін
}

Київський національний університет імені Тараса Шевченка, Київ, Украйна

Підвищення температури навколишнього середовища - один із найпоширеніших факторів стресу для організму рослин. Вивчення адаптації рослин до стресових факторів залишається надзвичайно важливим і актуальним. У статті наведено результати різкого короткотривалого впливу гіпертермії на окремі види двох підродів роду Haworthia Duval. Досліджено різні ланки антиоксидантного захисту та ступінь пошкодження представників двох підродів роду Haworthia на біохімічному рівні, а також посухостійкість цих рослин. Дослідні рослини нагрівали в термостаті за температури 40 та $50^{\circ} \mathrm{C}$ протягом трьох годин в умовах природного освітлення. Контрольну групу рослин тримали за $25^{\circ} \mathrm{C}$. Різке підвищення температури викликає найбільше перекисне окиснення ліпідів у рослин $H$. parksiana, разом із тим під час прогрівання до $50{ }^{\circ} \mathrm{C}$ вмикається механізм активації та синтезу супероксиддисмутази та флавоноїдів. Досліджені види підроду Наworthia мають стійку до температурного стресу фотосинтетичну систему, ніж види підроду Hexangulares. У $H$. limifolia відбувається незначне пригнічення фотосинтезу. Адаптація H. суmbiformis до температурного стресу відбувається за рахунок стратегії накопичення за нормальних умов пулу активних ферментів супероксиддисмутази, пероксидази, флавоноїдів, а також активації пероксидази внаслідок стресу. 
Для H. attenuata характерне зростання активності ферментів супероксиддисмутази та пероксидази внаслідок стресу. H. сутbiformis i H. attenuata більш жаростійкі порівняно з двома іншими видами, а посухостійкість найвища у H. limifolia, а найнижча у H. сутbiformis, iнші два види з різних підродів мають подібні між собою показники посухостійкості. Не виявлено залежності механізмів дії антиоксидантної системи за гіпертермії від типу пристосування до аридних умов на анатомічному рівні в рослин різних підродів роду Наwоrthia.

Ключові слова: антиоксидантна система; супероксиддисмутаза; пероксидаза; малоновий діальдегід; пігменти; посухостійкість

\section{Вступ}

Упродовж останніх десятиліть в усьому світі спостерігається стійка тенденція до підвищення середньорічних температур повітря (Hansen et al., 1999; Jones and Moberg, 2003; Bita and Gerats, 2013). Погодно-кліматичні умови стають все більш нестабільними. Гіпертермія, а також інші абіотичні стресові чинники, як відомо, викликають окисний стрес у різних рослин (Hernandez et al., 2000; Mittler et al., 2004). Супероксиддисмутаза, каталаза та пероксидаза - перша ланка захисту клітин від активних форм кисню (Grant, 2000; Caverzan et al., 2012; Mansoor and Naqvi, 2013). Якщо активність ферментів антиоксидантної системи зростає, можна припустити, що адаптація відбувається успішно. Висока чутливість фотосинтетичного апарату рослин також використовується як маркер негативного впливу факторів довкілля (Chen et al., 2012; Ashraf and Harris, 2013; Martinazzo et al., 2013). Дослідження адаптивних механізмів проводили в основному на сільськогосподарських культурах (Sunkar, 2006; Rai et al., 2015; Rodríguez et al., 2015), у той час як сукулентам не приділяли достатньої уваги (Ardelean, 2014). Сукуленти, як правило, характеризуються високою посухо- та теплостійкістю. Проте представники різних родів мають різні критичні температури та методи адаптації до високих температур і посушливих умов і особливо чутливі до негативних чинників на ранніх стадіях розвитку (Zutta et al., 2011; Rosas et al., 2012). Сукулентні рослини роду Haworthia Duval (Asphodelaceae) - ендеміки Південної Африки, де вони поширені на кам'янистих грунтах у саванах, на схилах гір і горбів (Eggli, 2001). Більшість таксонів включені до Червоного списку рослин Південної Африки та мають різні категорії рідкісності (Red List of South Africa Plants, 2009). Рід нараховує близько 200 видів, різновидів і форм, поділених на три підроди (Bayer, 1999). В основу поділу рослин на підроди покладена морфологічна будова квітки, але наші дослідження показали, що рослини двох підродів (Haworthia та Hexangulares) характеризуються також відмінними пристосуваннями до аридних умов на анатомічному рівні (Nuzhyna and Gaydarzhy, 2015). Тому мета цієі статті - виявити біохімічні зміни представників роду Haworthia, які відбуваються в результаті впливу короткочасної гіпертермії, проаналізувати відмінності роботи антиоксидантної системи за різних анатомічних пристосувань, що дозволять виявити особливості адаптації конкретних видів, а також роду в цілому.

\section{Матеріал і методи досліджень}

Об'єкти досліджень - чотири рідкісні види 3 двох підродів роду Haworthia з Колекції сукулентних рослин Ботанічного саду імені академіка О. В. Фоміна (табл. 1).

В експерименті використано листя середнього ярусу дворічних рослин, вирощених в оранжерейних умовах. Дослідження проводили у другій декаді травня, коли денна температура повітря у приміщенні з рослинами становила $+23 \ldots+25{ }^{\circ} \mathrm{C}$, на не пристосованих до високих температур рослинах. Дослідні рослини у горщиках із землею прогрівали у повітряному термостаті за температури +40 та $+50{ }^{\circ} \mathrm{C}$ протягом трьох годин. Температуру в термостаті контролювали термометром, розміщеним на рівні рослин. Передня стінка термостата була скляною, рослини утримували за природного освітлення. Ми не використовували додаткового освітлення під час термообробки, оскільки відомі факти про посилення інгібувальної дії високих температур на фотосинтетичну систему за яскравого освітлення (Foyer and Harbinson, 1994). Контрольну групу рос- лин витримували за температури $+25^{\circ} \mathrm{C}$. Біохімічні дослідження проводили за допомогою спектрофотометра СФ-2000 (Spectr, Russia). Перекисне окиснення ліпідів установлювали за вмістом малонового діальдегіду, визначеного за кольоровою реакцією з тіобарбітуровою кислотою, заснованою на утворенні в кислому середовищі забарвленого триметинового комплексу, що має характерний спектр поглинання з максимумом 533 нм. Кількість малонового діальдегіду виражали в мкмоль/г сирої маси (Kumar and Knowles, 1993).

\section{Таблиця 1}

Ступінь рідкісності експериментальних рослин

\begin{tabular}{clc}
\hline Підрід & \multicolumn{1}{c}{ Вид } & $\begin{array}{c}\text { Ступінь } \\
\text { рідкісності }\end{array}$ \\
\hline \multirow{2}{*}{ Haworthia } & Haworthia cymbiformis (Haworth) Duval & LC \\
& H. parksiana v. Poellnitz. & CR \\
Hexangulares & H. attenuata Haworth & EN \\
& H. limifolia Marloth & VU \\
\hline
\end{tabular}

Активність супероксиддисмутази визначали за допомогою методу, заснованого на здатності супероксиддисмутази конкурувати з нітросинім тетразолієм за супероксидні радикали, що надходять із реакції фотоокиснення рибофлавіну за 560 нм. Активність супероксиддисмутази виражали у відносних одиницях активності на 1 мг білка (Giannopolitis and Ries, 1977). Вміст білка визначали методом Sibgatullina et al. (2011) за 595 нм, у мг/г сирої речовини.

Активність пероксидази визначали за швидкістю реакції окиснення бензидину до утворення синього продукту його окиснення за присутності $\mathrm{H}_{2} \mathrm{O}_{2}$ та пероксидази за 590 нм. Активність пероксидази виражали у відносних одиницях активності на 1 г сухої маси (Sharifi and Ebrahimzadeh, 2010).

Сумарний вміст флавоноїдів у перерахунку на рутин і абсолютно суху масу у відсотках визначали за методикою Trineeva et al. (2014) за довжини хвилі 410 нм.

Пігменти екстрагували з рослинного матеріалу $80 \%$ ацетоном і визначали спектрофотометричним методом за 663, 646, 470 нм (Lichtenthaller, 1987). Вміст пігментів визначали з розрахунку на масу сирої речовини.

Із метою визначення посухостійкості рослин за методикою Giang and Tokhtar' (2011) вимірювали оводненість тканин, водний дефіцит і втрату води за одну годину в’янення.

Статистичну обробку даних проводили за допомогою програми Prism GraphPad 6 (GraphPad Software, Inc., USA, 2012). Достовірність відмінностей результатів визначали за ANOVA.

\section{Результати}

Визначення рівня перекисного окиснення ліпідів важливе для розуміння розвитку реакції рослинних клітин на стрес. Накопичення малонового діальдегіду свідчить про низьку стійкість рослин до несприятливих зовнішніх умов. Для Н. attenuata, H. limifolia та $H$. cymbiformis характерна тенденція до збільшення концентрації малонового діальдегіду за $+40 \mathrm{ra}+50^{\circ} \mathrm{C}$, однак достовірної різниці значень не отримано, що вказує на відносну стійкість до різкої дії високих температур цих рослин. У H. parksiana достовірно збільшилась кількість малонового діальдегіду, особливо $3 \mathrm{a}+40{ }^{\circ} \mathrm{C}$, що, ймовірно, можна пояснити малоефективною роботою антиоксидантної системи у рослин цього виду за незначного збільшення температури (рис. $1 a$ ).

Дія високої температури викликає зниження активності супероксиддисмутази в усіх досліджених видів рослин. У Н. сутbiformis за нормальних умов формується найпотужніший запас супероксиддисмутази (рис. 1б), що дає можливість швидкої реакції 
на короткотривалу стресову дію, тобто цей фермент відіграє значну роль в адаптивних реакціях цих рослин. Найменша кількість супероксиддисмутази за нормальних умов у H. parksiana відповідає найсильнішому перекисному окисненню ліпідів до та після різкого прогрівання до $+40^{\circ} \mathrm{C}$. У цього виду за $+50{ }^{\circ} \mathrm{C}$ перекисне окиснення ліпідів виявлене меншою мірою, ніж за прогрівання $+40^{\circ} \mathrm{C}$, що, ймовірно, пов'язано 3 активацією супероксиддисмутази. Тобто за $+40{ }^{\circ} \mathrm{C}$ йде використання наявного пулу супероксиддисмутази, а за інтенсивнішого стресового чинника $\left(+50{ }^{\circ} \mathrm{C}\right)$ запускається активація або синтез цих антиоксидантних ферментів. Досліджуючи пероксидазу, можна відмітити значне зростання іiі
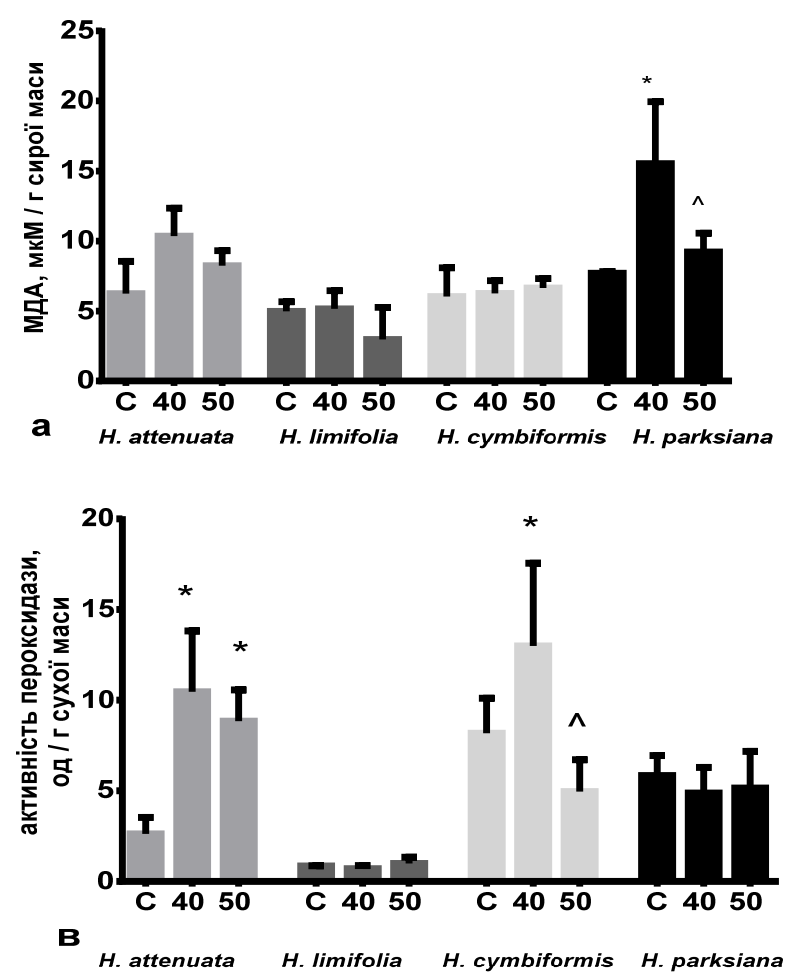

активності в $H$. cymbiformis і $H$. attenuata, що вказує на потужну антиоксидантну дію за гіпертермії (рис. 16). Причому активність пероксидази у цих видів за $+40{ }^{\circ} \mathrm{C}$ вища, ніж за $+50{ }^{\circ} \mathrm{C}$. Для H. cymbiformis, як і у випадку з супероксиддисмутазою, характерний найбільший пул пероксидази в нормі (порівняно з іншими дослідженими видами), з подальшим зростанням активності ферменту за помірного підвищення температури та, ймовірно, збалансованим утворенням - використанням даного ферменту за інтенсивного збільшення температури $\left(+50^{\circ} \mathrm{C}\right)$. На відміну від інших досліджених видів, у H. limifolia та H. parksiana пероксидаза відіграє незначну роль у захисній реакції на температурний стрес.
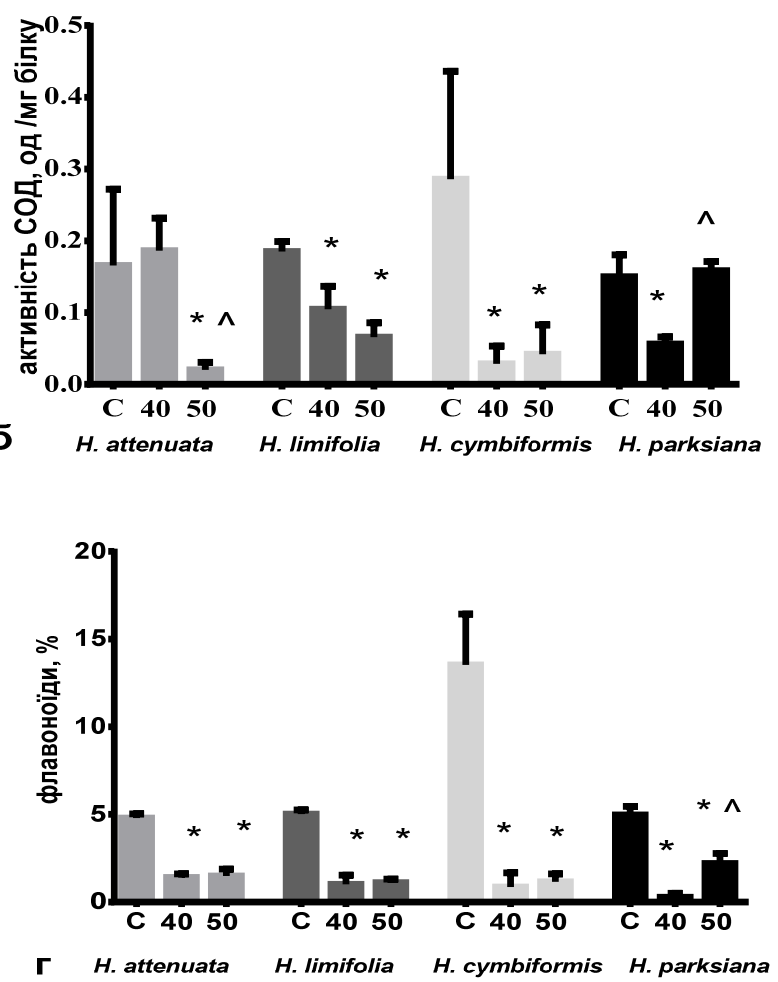

Рис. 1. Стан антиоксидантної системи за гіпертермії $(\mathrm{X} \pm \mathrm{SD}, \mathrm{n}=6)$ :

* - $\mathrm{P}<0,05$ відносно контролю, ${ }^{\wedge}$ - відносно групи $+40^{\circ} \mathrm{C} ; \mathrm{MДА} \mathrm{-} \mathrm{малоновий} \mathrm{діальдегід,} \mathrm{СОД} \mathrm{-} \mathrm{супероксиддисмутаза}$

Різке прогрівання рослин значно зменшувало кількість флавоноїдів у всіх дослідних групах, можливо, за рахунок їх руйнування. За отриманими даними, найбільше флавоноїдів у нормі накопичується у $H$. cymbiformis (рис. 12), що забезпечує цим рослинам певний антиоксидантний захист, особливо на перших етапах температурного стресу. Певне збільшення кількості флавоноїдів за $+50{ }^{\circ} \mathrm{C}$ порівняно $3+40{ }^{\circ} \mathrm{C}$ у H. parksiana, можливо, свідчить про включення додаткового захисного механізму за дії інтенсивнішого стресу.

Короткотривале прогрівання рослин $H$. attenuata $3 \mathrm{a}+40{ }^{\circ} \mathrm{C}$ викликає підвищення кількості хлорофілів і каротиноїдів (рис. $2 a$ ), що, можливо, є адаптивною відповіддю на таку зміну температурного режиму. За прогрівання $+50{ }^{\circ} \mathrm{C}$ спостерігається збільшення кількості лише каротиноїдів порівняно з контролем. Такі показники свідчать про досить високу пристосованість рослин даного виду до підвищення температури. Зниження співвідношення хлорофілу $a$ до хлорофілу $b$ спричинене інтенсивнішим збільшенням кількості останнього (рис. 2б).

Іншим чином впливає підвищення температури на пігментну систему H. limifolia. Зокрема, прогрівання до $+40{ }^{\circ} \mathrm{C}$ зумовлює незначне пригнічення фотосинтезу за рахунок зменшення кількості хлорофілів, тоді як за температури $+50{ }^{\circ} \mathrm{C}$ зменшується також і кількість каротиноїдів, що відображається на показнику відношення суми хлорофілів до каротиноїдів (рис. $3 a$, б). Інтенсивніше руйнування хлорофілів $b$ пояснює зростання показника співвідношення хлорофілу $a$ до хлорофілу $b$. Подібні результати отримано і для представників родини Cactaceae Juss. (Nuzhyna et. al., 2016).
За літературними даними, утримання Opuntia ficus-indica протягом однієї години $3 \mathrm{a}+55{ }^{\circ} \mathrm{C}$ повністю інгібувало поглинання $\mathrm{CO}_{2}$, але повне відновлення цього процесу відбувалося через 60 діб. Спостерігали диференціальну інактивацію фотосистеми I, фотосистеми II і всього ланцюга перенесення електронів; фотосистема I виявилась найвитривалішою $3 \mathrm{a}+55{ }^{\circ} \mathrm{C}$ і відновилася найшвидше (через 45 діб) (Chetti and Nobel, 1988).

Картина впливу короткотривалого температурного стресу на рослини H. cymbiformis в цілому подібна до такої у H. limifolia, відрізняється лише наявністю тенденції до зменшення кількості каротиноїдів уже за температури $+40{ }^{\circ} \mathrm{C}$, що відображається на показнику (хлорофіл $a+$ хлорофіл $b$ ) / каротиноїди (рис. 4). Співвідношення хлорофілу $a$ до хлорофілу $b$, а також суми хлорофілів до каротиноїдів достовірно не змінюється після короткотривалого високотемпературного стресу.

Для рослин $H$. parksiana, подібно $H$. attenuata, характерне збільшення або тенденція до збільшення кількості основних пігментів фотосинтетичної системи за короткотривалої дії температури $+40{ }^{\circ} \mathrm{C}$, а також $+50{ }^{\circ} \mathrm{C}$ (рис. $5 a$ ). Однак збільшення адаптивної відповіді за рахунок каротиноїдів спостерігається лише за $+40{ }^{\circ} \mathrm{C}$, що зумовлює достовірну відмінність між співвідношенням суми хлорофілів до каротиноїдів за короткотривалих дій температур різної інтенсивності. У H. parksiana за температури $+40{ }^{\circ} \mathrm{C}$ стабільним залишилось співвідношення хлорофілу $a$ до хлорофілу $b$ та (хлорофіл $a+$ хлорофіл $b$ ) / каротиноїди (рис. 5б). Дані співвідношення - критерії фотосинтетичної активності, їх використовують як маркери стійкості до стресових умов. 

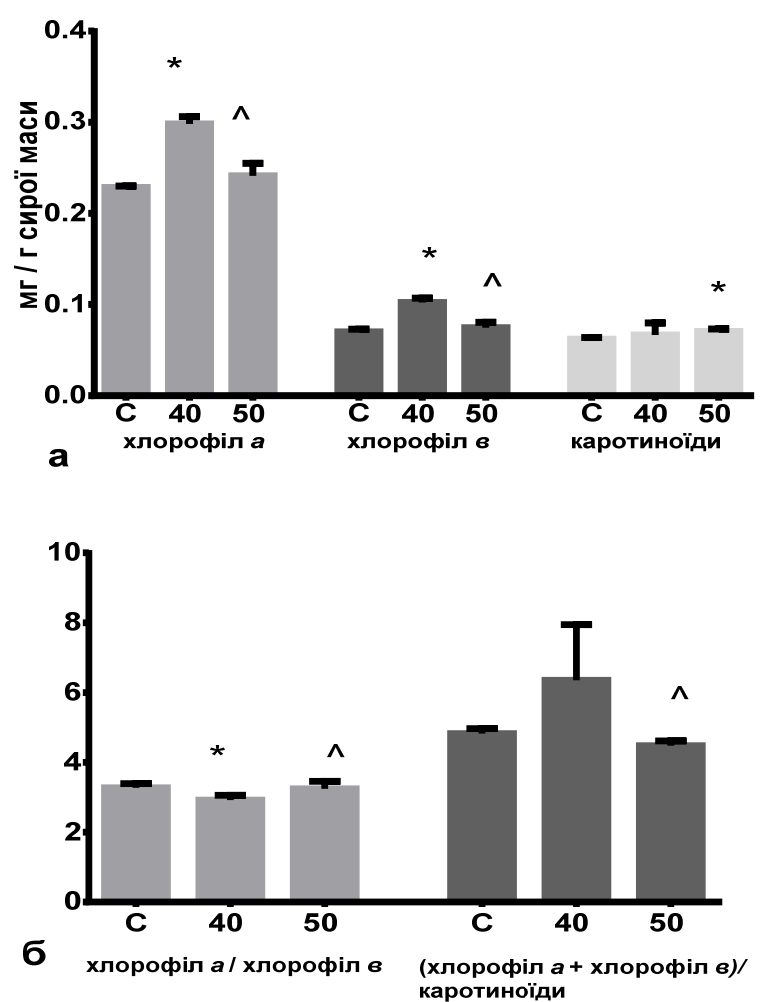

Рис. 2. Зміни пігментного складу H. attenuata після впливу високих температур: * $-\mathrm{P}<0,05$ відносно контрольної групи, ${ }^{\wedge}-\mathrm{P}<0,05$ відносно $+40{ }^{\circ} \mathrm{C}$

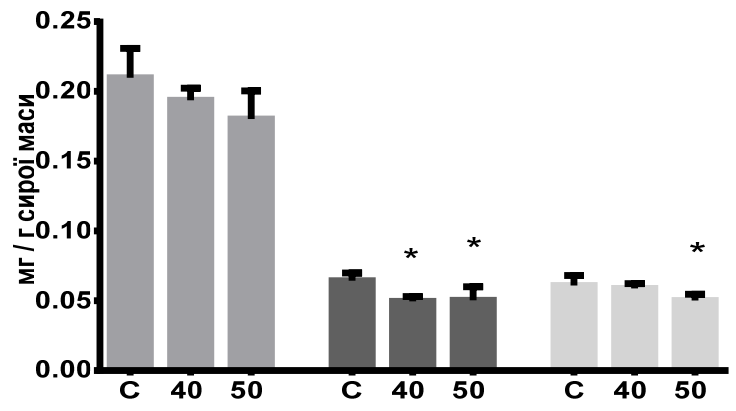

а хлорофіла хлорофіл в каротиноїди

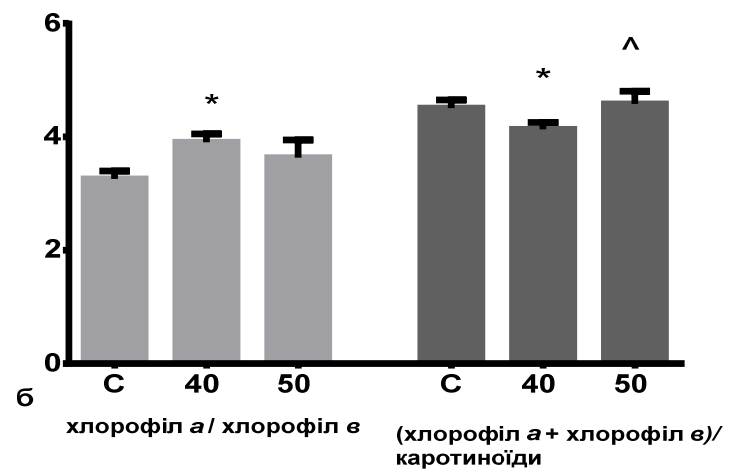

Рис. 3. Зміни пігментного складу H. limifolia після впливу високих температур: * $-\mathrm{P}<0,05$ відносно контрольної групи, $\wedge-\mathrm{P}<0,05$ відносно $+40^{\circ} \mathrm{C}$

Як відомо, вміст хлорофілів у листку відображає пристосованість рослини до певної інтенсивності освітлення. Досить низький вміст пігментів у нормі та дослідних групах $H$. cymbiformis можна пояснити найменшою кількістю шарів хлоренхіми серед розглянутих видів (Nuzhyna and Gaydarzhy, 2015), що вказує на більшу світлолюбність рослин цього виду. Кількісні показники фотосинтетичних пігментів найбільші у $H$. attenuata, це вказує на порівняно більшу тіньовитривалість.

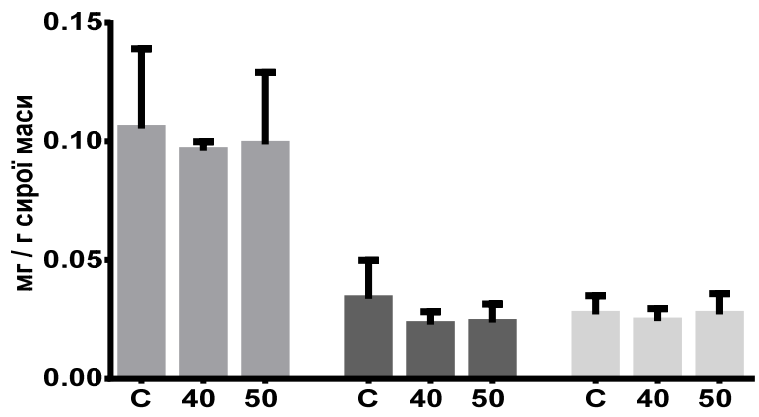

a хлорофіл а хлорофіл в каротиноїди

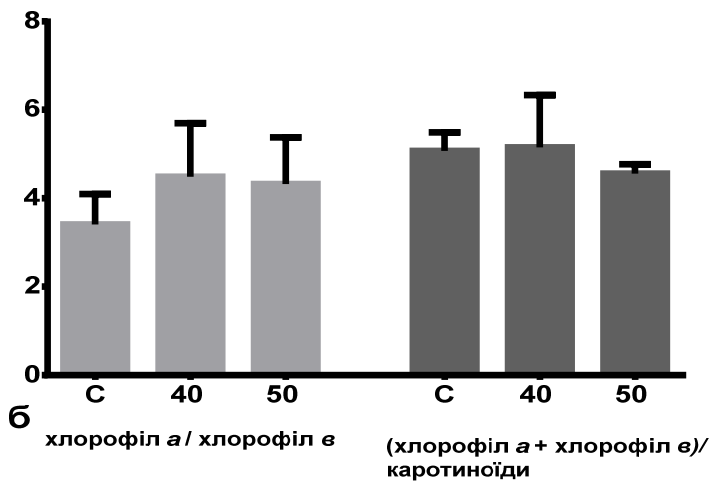

Рис. 4. Зміни пігментного складу H. cymbiformis після впливу високих температур: * $-\mathrm{P}<0,05$ відносно контрольної групи, $\wedge-\mathrm{P}<0,05$ відносно $+40{ }^{\circ} \mathrm{C}$

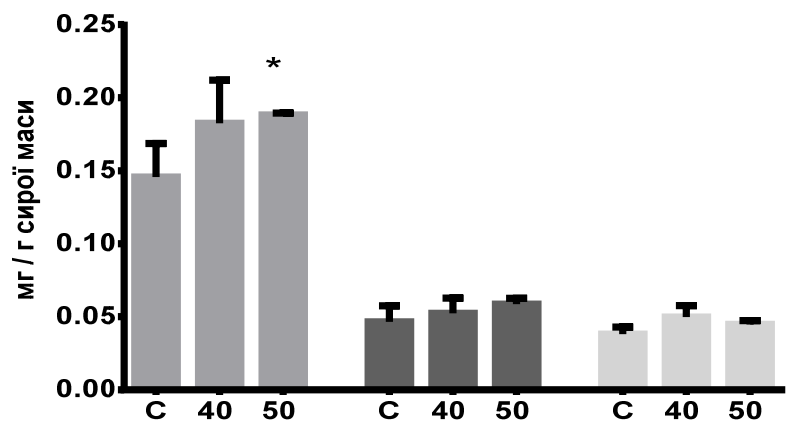

а хлорофіл а хлорофіл в каротиноїди

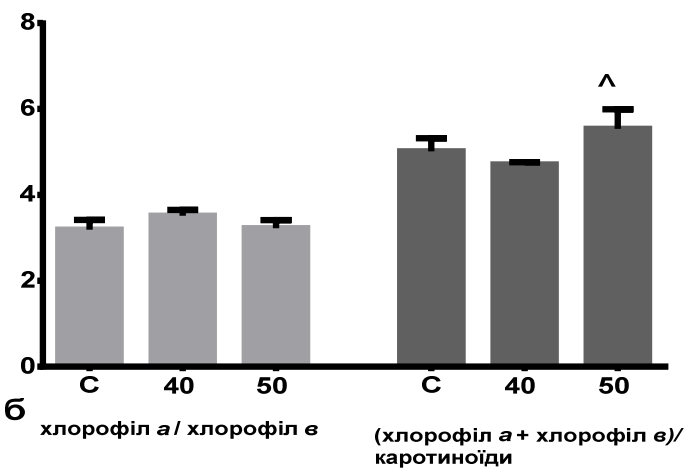

Рис. 5. Гістограма зміни пігментного складу $H$. parksiana після впливу високих температур: * $-\mathrm{P}<0,05$ відносно контрольної групи, ${ }^{\wedge}-\mathrm{P}<0,05$ відносно $+40{ }^{\circ} \mathrm{C}$

Дослідження посухостійкості рослин роду Haworthia показують високий вміст води в листках, що характерно для суку- 
лентних рослин (табл. 2). Найбільша оводненість листків спостерігається у H. cymbiformis. Дефіцит води характеризує недонасиченість рослин водою. Цей показник найвищий у H. parksiana. Здатність утримання води використовують як основний параметр стійкості рослин до посухи. Ї̈̈ оцінюють за швидкістю вивільнення води вегетативними органами. У нашому дослідженні H. cymbiformis показує максимальне значення втрати води за годину в'янення.

Таблиця 2

Посухостійкість представників роду Haworthia (x \pm SD, n = 10)

\begin{tabular}{lccc}
\hline \multicolumn{1}{c}{ Види } & $\begin{array}{c}\text { Втрата води } \\
\text { за 1 годину в’янення, \% }\end{array}$ & $\begin{array}{c}\text { Оводненість } \\
\text { тканин, \% }\end{array}$ & $\begin{array}{c}\text { Водний } \\
\text { дефіцит, \% }\end{array}$ \\
\hline H. attenuata & $7,53 \pm 2,9$ & $89,02 \pm 1,2$ & $6,51 \pm 1,1$ \\
H. limifolia & $4,32 \pm 0,7$ & $88,12 \pm 1,1$ & $5,88 \pm 0,8$ \\
H. cymbiformis & $22,29 \pm 4,4$ & $95,41 \pm 1,3$ & $5,35 \pm 2,3$ \\
H. parksiana & $7,44 \pm 4,6$ & $89,15 \pm 2,1$ & $6,88 \pm 1,4$ \\
\hline
\end{tabular}

\section{Обговорення}

Різке підвищення температури викликає найбільше перекисне окиснення ліпідів у рослин $H$. parksiana. Рослини цього виду мають відносно тонку епідерму та кутикулу (Nuzhyna and Gaydarzhy, 2015), що, можливо, $\epsilon$ однією 3 передумов низької терморезистентності досліджуваних рослин. Разом із тим, у них під час прогрівання до $+50{ }^{\circ} \mathrm{C}$ вмикаються механізми адаптації на рівні супероксиддисмутази та флавоноїдів. Різкий вплив гіпертермії на рослини $H$. limifolia, як і на рослини інших дослідних видів, викликає пригнічення активності супероксиддисмутази та зменшення кількості флавоноїдів. Це підтверджується літературними даними стосовно інших рослин (Smirnoff, 1993; Zhang and Kirkham, 1994). За літературними даними, зниження активності супероксиддисмутази внаслідок стресу пов'язане саме 3 денатурацією цього ферменту (Barkasdjieva et al., 2000; Rizhsky et al., 2002). Деякі дослідники спостерігали різноспрямовані реакції супероксиддисмутази на тепловий стрес різної інтенсивності у рослин різних видів, що вказує на різні способи адаптації (Panda and Khan, 2004; He, 2010; Harsha, 2016). У H. attenuata та $H$. cymbiformis внаслідок різкого підвищення температури спостерігається підвищення активності пероксидази. Підвищення активності пероксидази у відповідь на високотемпературну обробку також підтвердили інші дослідники (He, 2010; Ardelean et al., 2014). Адаптація H. cymbiformis до температурного стресу відбувається за рахунок стратегії накопичення за нормальних умов пулу активних супероксиддисмутази, пероксидази, флавоноїдів, а також активації пероксидази внаслідок стресу. Таким чином, H. cymbiformis та H. attenuata краще адаптовані до різкої зміни температури на рівні антиоксидантної системи порівняно $з$ двома іншими видами, хоча і належать до різних підродів. Тому не можна стверджувати, що тип пристосування до аридних умов на анатомічному рівні у рослин підроду Haworthia (збільшення накопичення води, наявності «вікон», продихи меншого розміру та тонша зовнішня стінка клітин епідерми) чи тип пристосування, характерний представникам підроду Hexangulares (зменшення транспірації, наявність сосочків і потовщена епідерма та ії̈ зовнішня клітинна стінка) (Nuzhyna and Gaydarzhy, 2015) ефективніший. Також не виявлено односпрямованого пристосування на біохімічному рівні до температурного стресу за односпрямованої адаптації на анатомічному рівні.

Дослідження фотосинтетичної системи рослин - одна 3 важливих ланок у напрямку розуміння їх адаптації до температурних стресових факторів (Zutta et al., 2011). Пігментний склад фотосинтетичного апарату формується залежно від генотипу, екологічних умов і періоду розвитку рослини (Nepliy et al., 2013). На представниках Сасtасеае показано деструктивні зміни в хлоренхімі вже за одногодинного прогрівання $+46{ }^{\circ} \mathrm{C}$ (Didden-Zopfy and Nobel, 1982). Загартовування ж рослин шляхом поступового підвищення денної та нічної температури повітря значно збільшило їх жаростійкість (Didden-Zopfy and
Nobel, 1982; Chetti and Nobel, 1988). Тому саме різкі температурні зміни небезпечні для цих рослин.

Важливо зазначити, що пігментна система у $H$. attenuata краще пристосована до різких температурних коливань, порівняно з іншими видами, за рахунок вмикання адаптивних механізмів. У $H$. parksiana захисна реакція вмикається лише за $+50{ }^{\circ} \mathrm{C}$, а за $+40{ }^{\circ} \mathrm{C}$ достовірних змін не відбувається. Разом із цим, кількість світлозбиральних пігментів у H. cymbiformis достовірно не змінюється, що теж свідчить про певну стабільність системи до дії гіпертемії. Лише у H. limifolia відбувається незначне пригнічення фотосинтезу. Тобто можна говорити про більшу інертність фотосинтетичної системи до короткотривалої дії високих температур рослин підроду Haworthia відносно підроду Hexangulares. Така стійкість може бути пояснена більшою кількістю продихів (а отже, кращою транспірацією та охолодженням листкової пластинки) у видів цього підроду, а також наявністю трихом та «вікон» (що також зменшує перегрівання) у H. parksiana (Nuzhyna and Gaydarzhy, 2015).

H. cymbiformis показує максимальне значення втрати води за годину в'янення, що відбувається, зокрема, через найбільшу серед досліджуваних видів кількість продихів, i, отже, вищу втрату води під час транспірації за підвищеної температури, а також найтоншу зовнішню клітинну стінку епідерми (Nuzhyna and Gaydarzhy, 2015). Аналізуючи анатомічну будову листків, можна виявити особливості, які впливають на посухостійкість рослин найбільше. Кутикула мало проникна для води та газу, тому захищає листки від надмірного випаровування. Згідно 3 нашими попередніми дослідженнями (Nuzhyna та Gaydarzhy, 2015), найкраще розвинена зовнішня клітинна стінка епідерми (у тому числі кутикула) у H. limifolia, яка, поряд із малою щільністю продихів, зумовлює найменшу втрату води за годину в’янення.

\section{Висновки}

За нашими даними, H. cymbiformis та $H$. attenuata жаростійкіші порівняно з двома іншими видами. Різка короткотривала гіпертермія впливає по-різному на антиоксидантну систему різних видів хавортій. Досліджені види підроду Haworthia мають стійкішу до температурного стресу фотосинтетичну систему ніж види підроду Hexangulares.

Посухостійкість найвища у H. limifolia та найнижча у H. cymbiformis, інші два види з різних підродів мають подібні між собою показники посухостійкості. Показники посухостійкості та стан фотосинтетичної системи за гіпертермії більше залежать від анатомічної структури, ніж механізм дії антиоксидантної системи.

\section{References}

Ardelean, M., Cachita-Cosma, D., Ardelean, A., Ladasius, C., \& Mihali, V. C. (2014). The effect of heat stress on hyperhydricity and guaiacol peroxidase activity (GPOX) at the foliar lamina of Sedum telephium L. ssp. maximum (L.) Krock. Vitroplantlets. Analele Ştiinţifice ale Universităţii „Al. I. Cuza” Iaşi s. II a. Biologie vegetală, Scientific Annals of „Alexandru Ioan Cuza”, University of Iasi, Biology Series. 60(2), 21-31.

Ashraf, M., \& Harris, P. J. C. (2013). Photosynthesis under stressful environments: An overview. Photosynthetica, 51(2), 163-190.

Barkasdjieva, N. T, Chrostov, K. N., \& Christina, K. N. (2000). Effect of calcium and zinc on the acivity and thermostability of superoxide dismuatse. Biologia Plantarum, 43, 73-78.

Bayer, B. (1999). Haworthia revisied. A revision of genus. Umdaus Press, Pretoria.

Bita, C. E., \& Gerats, T. (2013). Plant tolerance to high temperature in a changing environment: Scientific fundamentals and production of heat stress-tolerant crops. Frontiers in Plant Science, 4, 273-285.

Caverzan, G. Passaia, S., Rosa, S. B., Barcellos, R., Ribeiro, W. C., Lazzarotto, F., \& Margis-Pinheiro, M. (2012) Plant responses to stresses: Role of ascorbate peroxidase in the antioxidant protection. Genetics and Molecular Biology, 35(4), 1011-1019.

Chen, W. R., Zheng, J. S., Li, Y. Q., \& Guo, W. D. (2012). Effects of high temperature on photosynthesis, chlorophyll fluorescence, chloroplast ultrastructure, and antioxidant activities in fingered citron. Russian Journal of Plant Physiology, 59(6), 732-740. 
Chetti, M. B., \& Nobel, P. S. (1988). Recovery of photosynthetic reactions after hightemperature treatments of a heat-tolerant cactus. Photosynthesis Research, 18(3), 277-286.

Didden-Zopfy, B., \& Nobel, P. S. (1982). High temperature tolerance and heat acclimation of Opuntia bigelovii. Oecologia, 52(2), 176-180.

Eggli, U. (2001). Illustrated Handbook of succulent plants. Monocotyledones. Press: Springler-Verlag. Berlin, Heidelberg, New York.

Foyer, C. H., \& Harbinson, J. (1994). Oxygen metabolism and the regulation of photosynthetic electron transport. In: Causes of photooxidative stress and amelioration of defense system in plants. CRC Press, Boca Ratón, 1-42.

Giang, D., \& Tokhtar', V. K. (2011). Issledovanie zasuhoustoychivosti perspektivnyih vidov Momordica charantia L. i M. balsamina L. (Cucurbitaceae) [Drought resistance study of respective for introduction of Momordica charantia L. and M. balsamina L. Species (Cucurbitaceae)]. Nauchnyie Vedomosti. Seriya Estestvennyie Nauki, 9, 43-47 (in Russian).

Giannopolitis, C. N., \& Ries, S. K. (1977). Superoxide dismutase I. Occurrence in higher plants. Plant Physiology, 2, 309-314.

Grant, J. J. (2000). Role of active oxygen intermediates and cognate redox signaling in disease resistance. Plant Physiology, 124, 21-29.

Hansen, J., Ruedy, R., Glascoe, J., \& Sato, M. (1999). GISS analysis of surface temperature change. Journal of Geophysical Research, 104, 30997-31022.

Harsh, A., Sharma, Y. K., Joshi, U., Rampuria, S., Singh, G., Kumarb, S., \& Sharma, R. (2016). Effect of short-term heat stress on total sugars, proline and some antioxidant enzymes in moth bean (Vigna aconitifolia). Annals of Agricultural Sciences, 61(1), 57-64.

He, Y., \& Huang, B. (2010). Differential responses to heat stress in activities and isozymes of four antioxidant enzymes for two cultivars of kentucky bluegrass contrasting in heat tolerance. Journal of the American Society for Horticular Science. 135(2), 116-124.

Hernandez, J. A., Jiménez, A., Mullineaux, P., \& Sevilia, F. (2000). Tolerance of pea (Pisum sativum L.) to long term stress is associated with induction of antioxidant defences. Plant Cell and Environment, 23, 583-862.

Jones, P. D., \& Moberg, A. (2003). Hemispheric and large-scale surface air temperature variations: An extensive revision and an update to 2001. Journal of Climate, 16, 206-223.

Kumar, G. N. M., \& Knowles, N. R. (1993). Changes in lipid peroxidation and lipolitic and free radical scavenging enzyme activities during aging and sprouting of potato (Solanum tuberosum) seed-tubers. Plant Physiology, 102, 115-124.

Lichtenthaller, H. K. (1987). Chlorophylls and carotenoids, pigments of photosynthetic biomembranes. Methods in Enzymology, 148, 350-382.

Mansoor, S., \& Naqvi, F. N. (2013). Effect of heat stress on lipid peroxidation and antioxidant enzymes in mung bean (Vigna radiata L.) seedlings. African Journal of Biotechnology, 12(21), 3196-3203.

Martinazzo, E. G., Ramm, A., \& Bacarin, M. A. (2013). The chlorophyll a fluorescence as an indicator of the temperature stress in the leaves of Prunus persica. Brazilian Journal of Plant Physiology, 24(4).

Mittler, R., Vanderauwera, S., Gollery, M., \& Van Breusegem, F. (2004). Reactive oxygen gene network of plants. Trends in Plant Science, 9, 490-498.

Nepliy, L., Babayants, O., Molodchenkova, O., \& Lyashuk, N. L. (2013). Vplyv VZhKYa na kil'kisnyy vmist khlorofiliv, karotynoyidiv ta zahal'nykh tsukri u lystkakh ozymoyi pshenytsi v pivdennomu stepu Ukrayiny [Influence of HPLC on the quantitative content of chlorophylls, carotenoids and common sugars in leaves of winter wheat in the Southern Steppe of Ukraine]. Visnyk
Kyyivs'koho Natsional'noho Universytetu Ukrayiny. Seriya Biolohiya], 63, 29-33. (in Ukrainian).

Nuzhyna, N. V., \& Gaydarzhy, M. N. (2015). Comparative characteristics of anatomical and morphological adaptations of plants of two subgenera Haworthia Duval (Asphodelaceae) to arid environmental conditions. Acta Agrobotanika, 68(1), 23-31.

Nuzhyna, N., Bahlay, K., \& Avyekin, Y. (2016). Dynamika pihmentnoho kompleksu Echinocactus grusonii Hildm., Mammillaria bocasana Pos., Aylostera flavistyla Ritt. za umov hipertermiyi [Dynamics of the pigment complex Echinocactus grusonii Hildm., Mammillaria bocasana Pos., Aylostera flavistyla Ritt. under hyperthermia]. Visnyk Kyyivskogo Universytetu imeni Tarasa Shevchenka. Introduktsiya ta Zberezhennya Roslynnoho Riznomanittya, 34, 66-68 (in Ukrainian).

Panda, S. K., \& Khan, M. H. (2004). Changes in growth and superoxide dismutase activity in Hydrilla verticillata L. under abiotic stress. Brazilian Journal of Plant Physiology, 2, 115-118.

Rai, N., Rai, K. K., Tiwari, G., \& Singh, P. K. (2015). Changes in free radical generation, metabolites and antioxidant defense machinery in hyacinth bean (Lablab purpureus L.) in response to high temperature stress. Acta Physiologiae Plantarum, 37(3), 46-57.

Red List of South Africa Plants. Pretoria, (2009).

Rizhsky, L., Hongjian, L., Mittler, R. (2002). The combined effect of drought stress and heat shock on gene expression in tobacco. Plant Physiology, 130, 11431151.

Rodríguez, V. M., Soengas, P., Alonso-Villaverde, V., Sotelo, T., Cartea, M. E., \& Velasco, P. (2015). Effect of temperature stress on the early vegetative development of Brassica oleracea L. BMC Plant Biology, 15, 145.

Rosas, U., Zhou, R. W., Castillo, G., \& Collazo-Ortega, M. (2012). Developmental reaction norms for water stressed seedlings of succulent cacti. PLoS ONE, $7(3)$.

Sharifi, G., \& Ebrahimzadeh, H. (2010). Changes of antioxidant enzyme activities and isoenzyme profiles during in vitro shoot formation in saffron (Crocus sativus L.). Acta Biologica Hungarica, 61(1), 73-89.

Sibgatullina, G. V., Haertdinova, L. R., Gumerova, E. A., Akulov, A. N., Kostyukova, Y. A., Nikonorova, N. A., \& Rumyantsev, N. I. (2011). [Metody opredelenia redox-statusa kul'tiviruemyh kletok rasteniy] Methods for determining the redox status of cultured plant cells. Kazan Federal University, Kazan (in Russian).

Smirnoff, N. (1993) The role of active oxygen in response to water deficit and dessication. New Phytology, 125, 27-58.

Sunkar, R. (2006). Posttranscriptional induction of two $\mathrm{Cu} / \mathrm{Zn}$ superoxide dismutase genes in Arabidopsis is mediated by downregulation of miR398 and important for oxidative stress tolerance. Plant Cell, 18, 2051-2065.

Trineeva, O. V., Slivkin, A. I., \& Voropayeva, S. (2014). Razrabotka i validatsiya metodiki kolichestvennogo opredeleniya flavonoidov $\mathrm{v}$ listyah krapivyi dvudomnoy. [Development and validation of a technique of quantitative definition flavonoids in nettle leaves a two-blast furnace]. Vestnik VGU, Himiya, Biologiya, Farmatsiya, 1, 138-144 (in Russian).

Zhang, J., \& Kirkham, M. (1994). Drought-stress induced changes in activities of superoxide dismutase, catalase and peroxidases in wheat leaves. Plant Cell Physiology, 35, 785-791.

Zutta, B. R., Nobel, P. S., Aramians, A. M., \& Sahaghian, A. (2011). Low-and hightemperature tolerance and acclimation for chlorenchyma versus meristem of the cultivated cacti Nopalea cochenillifera, Opuntia robusta, and Selenicereus megalanthus. Journal of Botany, Article ID 347168. 